\title{
Performance Appraisal with Reference to Vst Motors Pvt Ltd, Chennai
}

\author{
R Ramamoorthy, Venkataraman K, Anish.S
}

\begin{abstract}
To discover the presentation of the worker. To consider the different strategies for a worker. To discover the fulfillment of the exhibition examination. $20 \%$ of the respondent as often as possible your presentation is examination. $25 \%$ of respondent of result evaluation are reasonable. $31 \%$ have you an ever been examination inside the association. $32 \%$ are happy with the results of examination. While surrounding the parameters in the positioning strategy the presentation evaluation system and gathering exchange can be made among and with different experts. Also, the procedures utilized for execution evaluation are conventional which is to be modernized in future for good prospect of the workers. HR are the essential wellspring of each association. Each representative in an association expands the profitability and generosity of each organization. A representative, being an individual is treated as resources in the association. So the association ought to for the most part accentuation execution examination procedures and its advancement program.
\end{abstract}

Keywords: Performance appraisal, Human resources, Productivity

\section{INTRODUCTION}

Execution examination is an essential piece of HRM and HRM manages staff is individuals. "Individuals" is the significant and profitable asset that each association or organization has as its representatives. Dynamic individuals can construct dynamic association[1],[3],[5]. Compelling workers can add to the viability of the association. HRM has various objectives, which incorporate employee $s$ competency improvement, representative inspiration advancement and association improvement. Representatives require an assortment of abilities, information, mentality, aptitudes in specialized zone; Managerial territories, social and human relations regions and applied zone to perform various assignments or capacities required by their employments[2 ],[4],[6]

HRM go for always the competency necessities of various individual to play out the activity allocated to them, viably and gives chances to building up these skills. As HRM manages people it is important to keep a beware of their exhibition after customary interim of time given

Revised Manuscript Received on July 22, 2019.

Mr R Ramamoorthy , Department of MBA, Bharath Institute of Higher Education and Research, Chennai, India.

Email: ramamoorthy0071@gmail.com

Venkataraman K, Department of Civil Engineering, Bharath Institute of Higher Education and Research, Chennai, India. Email: venkatraman.civil@bharathuniv.ac.in

Anish.S, Department of Civil Engineering, Bharath Institute of Higher Education and Research, Chennai, India.

Email: anishdavidpaul@gmail.com employments, it is important to restorative activities term or there is have to examination their presentation. The way toward assessing for doing their work adequately is known as execution evaluation framework.

It is major to fathom and improve the employee ${ }^{e e}$ execution assessment is the explanation behind HRD. It was seen that introduction assessment was useful to choose delegate progression/move, remuneration affirmation and such. Its hidden establishments in the mid twentieth century can be pursued to Taylor ${ }^{\text {ee }}$ s initiating Time and development ponders. As an undeniable and formal organization system used in the appraisal of work execution, assessment genuinely dates from the time World War - not more than 60years back.

\section{STATISTICAL TOOLS}

\section{$>$ PERCENTAGE METHOD $>$ CHI -SQUAR TEST}

Table - 1 How Frequently Your Performance Is Appraisal

\begin{tabular}{|l|l|l|}
\hline Particular & No of respondent & $\%$ \\
\hline Monthly & 23 & 23 \\
\hline Quarterly & 26 & 26 \\
\hline Semi annually & 46 & 46 \\
\hline Yearly & 5 & 5 \\
\hline Total & 100 & 100 \\
\hline
\end{tabular}
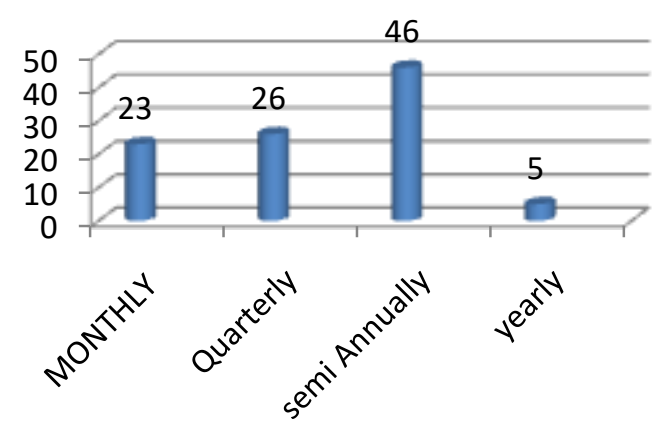

Figure - 1 How Frequently Your Performance Is Appraisal

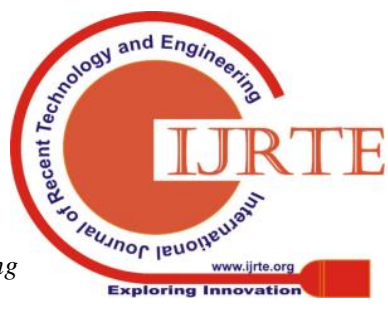


Table -2 The Result Of Appraisal Are Fair

\begin{tabular}{|l|l|l|}
\hline Particular & No of respondent & $\%$ \\
\hline Strongly agree & 15 & 15 \\
\hline Agree & 20 & 20 \\
\hline Neutral & 35 & 35 \\
\hline Disagree & 18 & 18 \\
\hline Strongly disagree & 12 & 12 \\
\hline Total & 100 & 100 \\
\hline
\end{tabular}

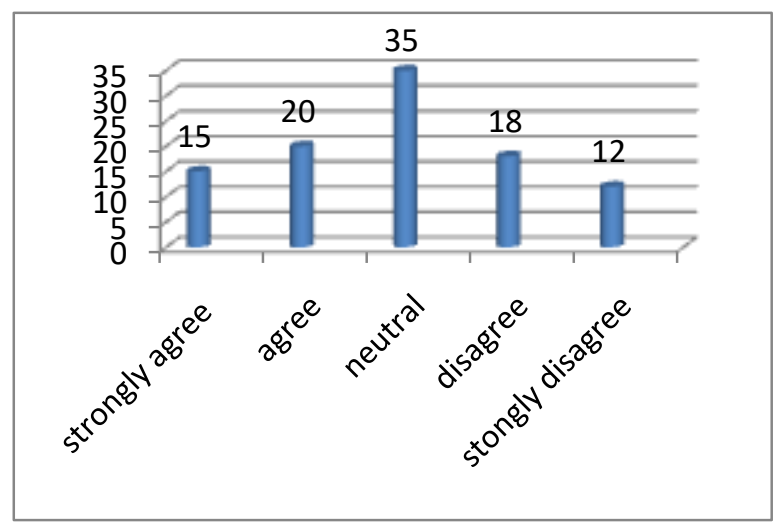

Figure - 2 The Result Of Appraisal Are Fair

Table - 3 Assessors Appraise Performance Without Any Business

\begin{tabular}{|l|l|l|}
\hline Particular & No of respondent & $\%$ \\
\hline Strongly agree & 35 & 35 \\
\hline Agree & 12 & 12 \\
\hline Neutral & 18 & 18 \\
\hline Disagree & 15 & 15 \\
\hline Strongly disagree & 20 & 20 \\
\hline Total & 100 & 100 \\
\hline
\end{tabular}

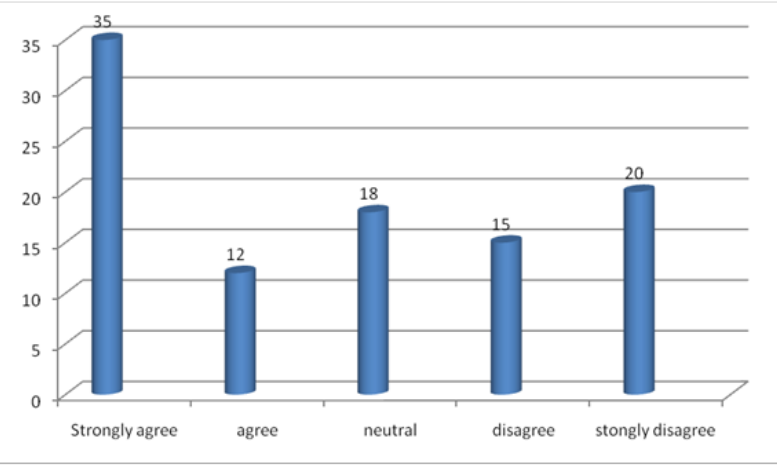

Figure - 3 Assessors Appraise Performance Without Any Business

Table - 4 Any Other Employee Is Not Prioritized During Performance Appraisal System

\begin{tabular}{|l|l|l|}
\hline Particular & No of respondent & $\%$ \\
\hline Strongly agree & 18 & 18 \\
\hline Agree & 32 & 32 \\
\hline Neutral & 12 & 12 \\
\hline Disagree & 20 & 20 \\
\hline Strongly disagree & 15 & 15 \\
\hline Total & 100 & 100 \\
\hline
\end{tabular}

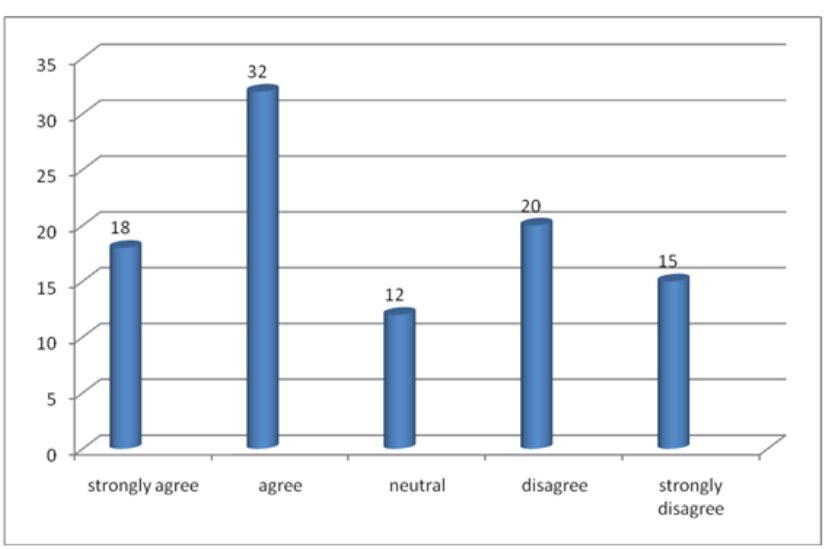

Table - 5 Appraisers Treat You Fairly During Performance Appraisal Process

\begin{tabular}{|l|l|l|}
\hline Particular & No of respondent & $\%$ \\
\hline Strongly agree & 20 & 20 \\
\hline Agree & 10 & 10 \\
\hline Neutral & 15 & 15 \\
\hline Disagree & 36 & 36 \\
\hline Strongly disagree & 19 & 19 \\
\hline Total & 100 & 100 \\
\hline & \multicolumn{2}{|c|}{} \\
\hline
\end{tabular}




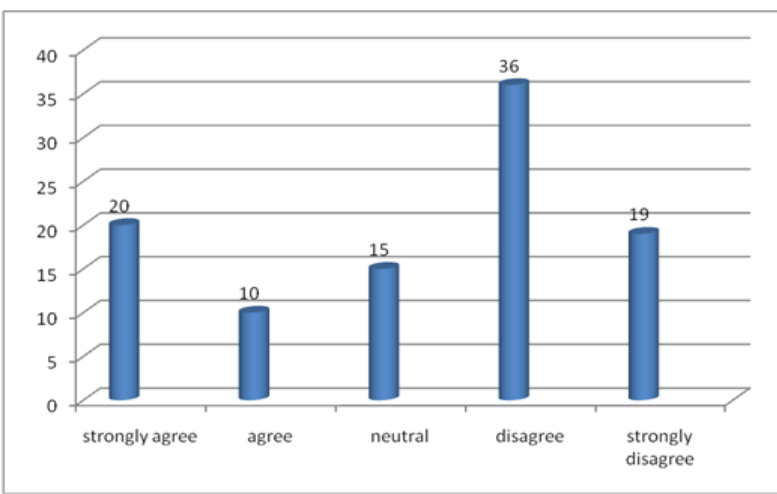

Figure - 5 Appraisers Treat You Fairly During Performance Appraisal Process

Table - 6 Appraisal Outcomes Are Accurate

\begin{tabular}{|l|l|l|}
\hline Particular & No of respondent & $\%$ \\
\hline Strongly agree & 18 & 18 \\
\hline Agree & 32 & 32 \\
\hline Neutral & 12 & 12 \\
\hline Disagree & 20 & 20 \\
\hline Strongly disagree & 15 & 15 \\
\hline Total & 100 & 100 \\
\hline
\end{tabular}

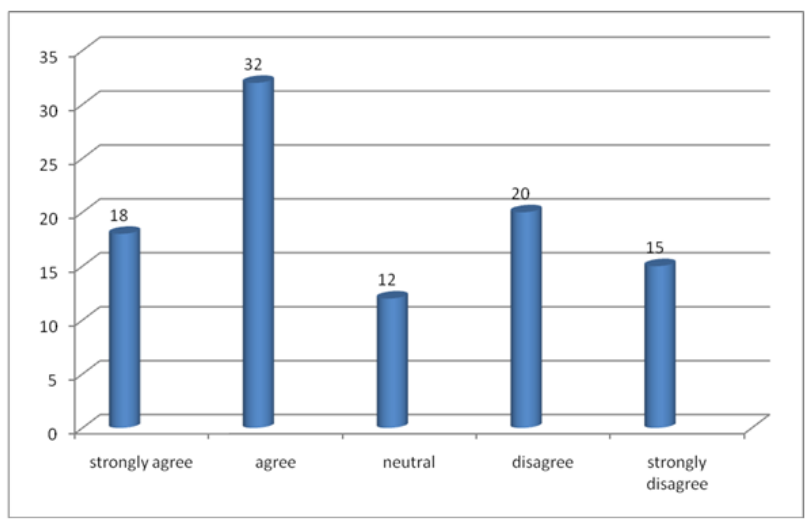

Figure - 6 Appraisal Outcomes Are Accurate

Table - 7 Minimum Errors Are Identified In The Appraisal

\begin{tabular}{|l|l|l|}
\hline Particular & No of respondent & $\%$ \\
\hline Strongly agree & 20 & 20 \\
\hline Agree & 10 & 10 \\
\hline Neutral & 15 & 15 \\
\hline Disagree & 36 & 36 \\
\hline Strongly disagree & 19 & 19 \\
\hline Total & 100 & 100 \\
\hline
\end{tabular}

\section{Alternate hypothesis(H1):}

There is significant difference between no of years customers associated with the company and no of time the problem encounter during the services time.

Expected frequency $=\quad$ Row Total $*$ Column Total

$\mathrm{X}^{2}$ col $=\mathbf{2 6 . 8 8}$

Calculated Value $(\mathrm{CV})=\mathbf{2 6 . 8 8}$

\section{DEGREES OF FREEDOM}

$\mathrm{V}=[\mathrm{r}-1][\mathrm{c}-1]$

$\mathrm{V}=[2-1][2-1]$

$\mathrm{V}=1 \mathrm{x} 1$

$\mathrm{V}=1$

Table Value $[T . V]=3.841$

Calculated Value $[\mathrm{C} . \mathrm{V}]=\mathbf{2 6 . 8 8}$

Therefore, Calculated value [C.V]> Table Value [T.V]

Hence, Ho is rejected 


\section{RESULTS}

- $41 \%$ of the respondents to the age social affair of 20-30years.

- $35 \%$ of the respondents have the capacity ITI/Diploma.

- $31 \%$ have you an ever been assessment inside the affiliation. [7],[ 9],[11]

- $20 \%$ of the respondent once in a while your introduction is assessment.

- $25 \%$ of respondent of result assessment are sensible.

- $35 \%$ of the respondents for solidly agree Assessors assess execution with no business.

- $32 \%$ of the respondents for agree some other delegate isn't sorted out during execution assessment structure

- $36 \%$ of the respondent for contrast Appraisal treats you sensibly during execution assessment process

- $32 \%$ agree for the Appraisal results are exact

- 36\%disagree for the Minimum goofs are recognized in the assessment system [8],[10],[12]

- $35 \%$ objective foe The enduring nature of outcomes of assessment structure are high

- $35 \%$ unequivocally agree you are allowed to discuss assessment result with executive

- $35 \%$ agree you are allowed to pass on contribution to the board as for assessment result

- $32 \%$ vary Interaction among you and the officials redesigns assessment reasonability

- $36 \%$ collaboration with boss and the officials also improvement your motivation

- $32 \%$ You are content with the aftereffects of assessment

- $36 \%$ You are content with the course by which your display is surveyed [13], [15],[17]

- $35 \%$ unbiased of the you envision that present assessment structure has requirement.

- $35 \%$ ) unbiased of the respondent for the Performance assessment has offered opportunity to improve execution

- $35 \%$ insistently agree Your motivation has extended through assessment results

- $32 \%$ agree Appraisal results have given you opportunity to crash weak districts in execution.

\section{DISCUSSIONS}

While enclosing the parameters in the situating technique the introduction assessment strategy and social occasion talk can be made among and with various experts. Additionally, the frameworks used for execution assessment are incredibly ordinary which is to be modernized in future for good prospect of the agents[14],[16], [18]
Addition the care level of delegates during the introduction assessment period. It will be better if the organization gives inspiring powers to delegates so it will bolster in their work and proficiency and moreover stretch out the probation time period up to 2 years. Separate rating leading group of trustees to be fixed during the assessment time span[19],[21],[23]

So that there is no assessing tendencies and individual inclination will occur. The display rating is extraordinarily valuable for the board to give specialist coordinating during the assessment. Execution assessment is just established on assessment structure and the rating fixes increment for workers make them held in the affiliation.

\section{V.CONCLUSION}

HR are the indispensable wellspring of each association. Each representative in an association builds the efficiency and altruism of each organization. A worker, being an individual is treated as resources in the association [20],[22], [24]. So the association ought to predominantly accentuation execution examination strategies and its improvement program.

Both the appraiser and assess ought to understand the guideline and utilize the apparatus of evaluation framework in a productive manner for the flourishing of the association. The exhibition evaluation procedure winning in the association is reasonable. Workers are happy with the present execution evaluation framework that is a conventional one[25],[27],[29]. The same number of new evaluation procedures are developed, the association can execute current strategy which would be progressively viable.

The welfare proportion of association is at standard with the organization strategies and has acquired an extraordinary feeling of inclusion work among the representatives of the association[26],[28],[30]. On the off chance that the recommended measures are contemplated it will build the adequacy of execution evaluation framework[31],[33].

\section{REFERENCES}

1) BharthVajan R., Ramachandran S.,Psychographic dimensions of training,2016,International Journal of Pharmacy and Technology,V-8,I-4,P-23727-23729

2) Balakrishnan P., Bharthvajan R.,A study on human resource planning in hospitals in Chennai City,2014,International Journal of Applied Engineering Research,V-9,I-22,P-7503-7507

3) Priyadarsini P., Bharthvajan R.,Role of emotional intelligence training programme in reducing the stress of the nurses,2014,International Journal of Applied Engineering Research,V-9,I-22,P-7411-7421

4) Kerinab Beenu G., Bharthvajan R.,Empirical analysis on the cosmetic buying behavior of young women in South India,2014,International Journal of Applied Engineering Research,V-9,I-22,P-7361-7366

5) Balakrishnan P., Bharthvajan R.,Whistling in the wind,2014,International Journal of Applied Engineering Research,V-9,I-22,P-7586-7593

6) Krishnan B., Peter M.,Health hazards of Indian Bpo employee-an alarming issue,2014,International Journal of Applied Engineering Research,V-9,I-22,P-7336-7341

7) Kerinab Beenu G.H., Peter M.,Role of insurance in economic development,2014,International 
Journal of Applied Engineering Research,V-9,I-22,P-7532-7539

8) Balakrishnan P., Peter M., Priyadarsini P.,Efficiency of safety measures for wellbeing of employees in manufacturing industry,2014,International Journal of Applied Engineering Research,V-9,I-22,P-7376-7382

9) Anbarasi M., Praveen Kumar S.,Online sales promotions of herbal products and its effectiveness towards tanisha.com,2019,Indian Journal of Public Health Research and Development,V-10,I-1,P-195-200

10) Anbarasi M., Praveen Kumar S.,Various online marketing and promotions strategies to improve the validation towards the organic products in the pharmaceutical sectors,2019,Indian Journal of Public Health Research and Development, V-10,I-1,P-263-269

11) Loganathan R., Praveen Kumar S.,Grievance handling a key factor for solving issues of employees in an organization,2014,International Journal of Applied Engineering Research,V-9,I-22,P-7483-7491

12) Loganathan R., Praveen Kumar S.,Study on preference of private label brands in super and Hypermarkets,2014,International Journal of Applied Engineering Research,V-9,I-22,P-7327-7335

13) Smitha M., Praveen Kumar S.,Understanding stress and its managementamong the nurses in Chennai city,2014,International Journal of Applied Engineering Research,V-9,I-22,P-7560-7565

14) Kerinab Beenu G.H., Praveen Kumar S.,A study on the investment behavior of Chennai investors in mutual fund schemes,2014,International Journal of Applied Engineering Research,V-9,I-22,P-7520-7525

15) Loganathan R., Praveen Kumar S.,Retention strategies key for organizational productivity,2014,International Journal of Applied Engineering Research, V-9,I-22,P-7443-7447

16) Pavithra J., Ganesan M., Brindha G.,State wise analysis of microfinance sector in India,2016,International Journal of Pharmacy and Technology, V-8,I-4,P-23417-23432

17) Pavithra J., Ganesan M.,A comparative study on microfinance in India and abroad,2016,International Journal of Applied Business and Economic Research,V-14,I-8,P-5471-5476

18) Pavithra J., Ganesan M.,A study on awareness and impact of micro-financial schemes,2016,International Journal of Applied Business and Economic Research,V-14,I-8,P-5449-5460

19) Senthilmurugan P., Pavithra J.,Consumer preference towards organised retailing with reference to Big Bazaar,2014,International Journal of Applied Engineering Research, V-9,I-22,P-7469-7475

20) Senthilmurugan P., Pavithra J.,Implication of social media marketing in growing healthcare industry,2014,International Journal of Applied Engineering Research,V-9,I-22,P-7448-7456

21) Loganathan R., Pavithra J.,Consumer perception towards private label brand over other brands in super markets and hypermarkets,2014,International Journal of Applied Engineering Research,V-9,I-22,P-7355-7360

22) Kerinab Beenu G., Pavithra J.,Tradeâ€"off between liquidity and profitability in logistics industry,2014,International Journal of Applied Engineering Research,V-9,I-22,P-7398-7401

23) Kerinab Beenu G., Pavithra J.,A study on the prospective consumerâ $€^{\mathrm{TM}_{\mathrm{S}}}$ perception towards utility cars in Chennai city,2014,International Journal of Applied Engineering Research,V-9,I-22,P-7526-7531

24) Pavithra J., Dilli Babu P., Ambuli T.V.,A study on budgetary control at Maruti Service Masters, Chennai,2014,International Journal of Applied Business and Economic Research,V-12,I-2,P-151-161

25) Pavithra J., Dilli Babu P., Ambuli T.V.,A study on customer satisfaction of retro Garments Pvt Ltd, Chennai,2014,International Journal of Applied Business and Economic Research,V-12,I-2,P-381-391

26) Kerinab Beenu G.H., Pavithra J., Senthilmurugan P.,A study on the influence of promotional activities for TATA ARIA among consumers in Chennai,2014,International Journal of Applied Engineering Research,V-9,I-22,P-7572-7578

27) Vijayaragavan S.P.,An investigative expert that's general FBG sensors,International Journal of Mechanical Engineering and Technology,V-8,I-8,PP-1500-1505,Y-2017

28) Vijayaragavan S.P.,Equalization routing protocol for Wi-Fi sensor strategy,International Journal of Mechanical Engineering and Technology,V-8,I-8,PP-1662-1666,Y-2017

29) Karthik B., Kiran Kumar T.V.U., Vijayaragavan P., Bharath Kumaran E.,Design of a digital PLL using 0.3511/4m CMOS technology,Middle East Journal of Scientific Research,V-18,I-12,PP-1803-1806,Y-2013

30) Kanniga E., Selvaramarathnam K., Sundararajan M.,Kandigital bike operating system,Middle - East Journal of Scientific Research,V

31) Jasmin M., Vigneshwaran T., Beulah Hemalatha S.,Design of power aware on chip embedded memory based FSM encoding in FPGA,International Journal of Applied Engineering Research,V-10,I-2,PP-4487-4496,Y-2015

32) Jasmin M.,Optimization techniques for low power VLSI circuits,Middle East Journal of Scientific Research,V-20,I-9,PP-1082-1087,Y-2014

33) Jasmin M., Vigneswaran T.,Fuzzy controller for error control of on - Chip communication,2017 International Conference on Algorithms,
Methodology, Models and Applications in Emerging Technologies, ICAMMAET 2017,V-2017-January,I-,PP-1-5,Y-2017

\section{AUTHORS PROFILE}

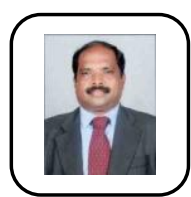

Mr R Ramamoorthy Assistant Professor, Departmen of MBA, Bharath Institute of Higher Education and Research, Chennai, India.

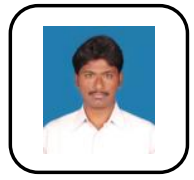

Venkataraman K Assistant Professor, Department of Civil Engineering, Bharath Institute of Higher Education and Research, Chennai, India.

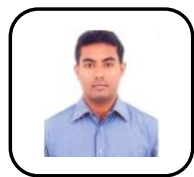

Anish.S Assistant Professor, Department of Civil Engineering, Bharath Institute of Higher Education and Research, Chennai, India. 